\title{
Congenital heart diseases and pregnancy, Universitary Hospital Center of Gynecology Obstetrical of Befelatanana, Madagascar
}

\author{
Tanjonirina Razafindrainibe ${ }^{1 *}$, Sidonie Rakotonomenjanahary ${ }^{2}$, Mamitiana Andrianirina $^{1}$, \\ Nasolotsiry E. Ravel ${ }^{3}$
}

\begin{abstract}
${ }^{1}$ Adult Intensive Care, Universitary Hospital Center of Gynecology Obstetrical of Befelatanana, Antananarivo Madagascar

${ }^{2}$ Department of Anasthesia, Universitary Hospital Center of Gynecology Obstetrical of Befelatanana, Antananarivo Madagascar

${ }^{3}$ Triage and Emergency Unit, Universitary Hospital Center of Gynecology Obstetrical of Befelatanana, Antananarivo Madagascar
\end{abstract}

Received: 13 June 2019

Accepted: 09 July 2019

\section{*Correspondence:}

Dr. Tanjonirina Razafindrainibe,

E-mail: rtanjna@gmail.com

Copyright: (C) the author(s), publisher and licensee Medip Academy. This is an open-access article distributed under the terms of the Creative Commons Attribution Non-Commercial License, which permits unrestricted non-commercial use, distribution, and reproduction in any medium, provided the original work is properly cited.

\begin{abstract}
Background: Congenital heart diseases are malformations formed during the first weeks of life. Thanks to advances in medicine, they could be cared properly and pregnancies on heart diseases could be continued and completed. These malformations are sources of morbidity even high maternal fetal mortality. Whence our motivation to carry out this study and improve its care.

Methods: This is a retrospective observational study reporting clinical cases of congenital heart disease pregnancies, only seen at the UHC-GOB over a seven years period (01 February 2007 - 28 February 2014).

Results: We have identified 10 cases of congenital heart diseases out of 56320 deliveries, that is, an incidence of 0.12 per 1000 deliveries. Isolated arterial canal persistence is predominant. The average age is $26 \pm 1$. Four cases of congenital heart diseases diagnosed and repaired during childhood, have been noted as well as 02 cases of fortuitous discovery during pregnancy. No joint obstetric and cardiac follow up was performed for our patients. Delivery by high way is recommended in $70 \%$ of cases which $57 \%$ under peridural anesthesia. Half of the patients had perigestational cardiac decompensation such as dyspnea, pre-eclampsia and vacuo-shock progressively decreasing in post-partum. On the fetal side, we recorded 01 intra-uterine delayed growths, 03 premature births and 02 deaths.

Conclusions: Pregnancy prognosis on congenital heart disease is based on the type of malformation, close follow up and a multidisciplinary care (Gyneco-obstetrician, Cardiologist, Reanimator, Pediatrician and Geneticist.
\end{abstract}

Keywords: Cardiac decomposition, Congenital heart disease, Pregnancy multidisciplinary care

\section{INTRODUCTION}

Congenital heart diseases are cardiac malformations formed during the first week of life. It can manifest itself from birth or discovered at adulthood. They constitute the most frequent malformations at birth affecting $0.8 \%$ of new born. The global prevalence is 2.8 to $4.09 / 1000{ }^{1}$
Advances, medical as well as surgical, in terms of diagnoses and care of these pathologies allowed a significant improvement of these patients survival. This aroused challenge for health staff particularly in the sphere of obstetrics where women with congenital heart disease of childbearing age continue to increase in numbers. In addition, maternal heart disease is associated with significant maternal morbidity and mortality. ${ }^{2}$ 
In Madagascar, the prevalence of congenital heart diseases is $5 / 1000$ and we note a low rate of surgical treatment of $2.2 \% .^{3}$ Pregnancies care on congenital heart disease still remains difficult and no multidisciplinary protocol is established. Whence, the interest of our work which aims to determine the profile of parturient carriers of congenital heart diseases and to evaluate the practices of care of practitioners in order to improve the care.

\section{METHODS}

This is a retrospective, observational study reporting the clinical cases of pregnancies on congenital disease within CHU-GOB over a period of 07 years from $01^{\text {st }}$ February 2007 till $28^{\text {th }}$ February 2014.

\section{Inclusion criteria}

- All congenital heart diseases well known or fortuitous discoveries.

\section{Exclusion criteria}

- Heart diseases unlabeled as congenital which means having an ambiguous congenital heart disease status.

\section{Statistical analysis}

The sampling was exhaustive. The qualitative variables were expressed in proportion and the quantitative variables on average with more or less standard deviation.

\section{RESULTS}

Out of 56320 deliveries listed during the study period, we selected 10 congenital heart diseases (Table 1), a prevalence of $0.12 / 1000$. A care of suspected but undocumented congenital heart disease was excluded. For demography parameters, the average maternal age is 26.6 with extremes of 17 and 39 years old. And the average gestational age is 34 weeks of amenorrhea and one day with extremes of 18 and 40 weeks. Regarding the clinical parameters, we have identified 04 inter auricular communications (IAC) of which one associated with a tetralogy of Fallot (TF).

Table 1: Cases of congenital heart diseases listed.

\begin{tabular}{|c|c|c|c|c|c|c|c|c|c|c|}
\hline Case & 1 & 2 & 3 & 4 & 5 & 6 & 7 & 8 & 9 & 10 \\
\hline Age (years) & 24 & 28 & 39 & 24 & 17 & 27 & 28 & 21 & 31 & 25 \\
\hline $\begin{array}{l}\text { Age } \\
\text { gestational } \\
\text { (Weeks) }\end{array}$ & 36 & 37,5 & 36,6 & 24 & 33 & 40 & 39,3 & 18 & 38 & 35,5 \\
\hline Type CHD & $\mathrm{IAC}+\mathrm{TF}$ & IAC & IAC & IAC & PAC & PAC & PAC & PAC & PAC & $\mathrm{PAC}+\mathrm{IVC}$ \\
\hline $\begin{array}{l}\text { Treatment } \\
\text { CHD }\end{array}$ & Surgery & 0 & 0 & 0 & 0 & 0 & 0 & Surgery & Surgery & Surgery \\
\hline $\begin{array}{l}\text { Repercussion } \\
\text { CHD }\end{array}$ & 0 & NYHAII & NYHAII & 0 & 0 & NYHAII/RM & TR-MR & 0 & 0 & $\begin{array}{l}\text { NYHAII- } \\
\text { HCM-MR }\end{array}$ \\
\hline $\begin{array}{l}\text { Motive for } \\
\text { admission }\end{array}$ & Dyspnea & $\mathrm{CS}$ & $\mathrm{CS}$ & $\begin{array}{l}\text { Threat of } \\
\text { abortion }\end{array}$ & Palpitation & Dyspnea & Contraction & $\begin{array}{l}\text { Threat } \\
\text { of } \\
\text { abortion }\end{array}$ & $\mathrm{CS}$ & $\mathrm{CS}$ \\
\hline $\begin{array}{l}\text { Clinique signs } \\
\text { at admission }\end{array}$ & NYHAIII & $\begin{array}{l}\text { Tachycardia- } \\
\text { BBD }\end{array}$ & 0 & $\begin{array}{l}\text { Tachycardia- } \\
\text { NYHAII }\end{array}$ & $\begin{array}{l}\text { Severe } \\
\text { preeclampsia }\end{array}$ & $\begin{array}{l}\text { cardiac } \\
\text { failure }\end{array}$ & 0 & 0 & 0 & $\begin{array}{l}\text { NYHAII- } \\
\text { Oedema }\end{array}$ \\
\hline $\begin{array}{l}\text { Maternal } \\
\text { evolution }\end{array}$ & $\begin{array}{l}\text { cardiac } \\
\text { arrest }+ \\
\text { convulsive } \\
\text { crises }\end{array}$ & $\begin{array}{l}\text { Regression } \\
\text { of signs }\end{array}$ & $\begin{array}{l}\text { Simple } \\
\text { evolution }\end{array}$ & $\begin{array}{l}\text { Regression } \\
\text { of signs }\end{array}$ & $\begin{array}{l}\text { Regression } \\
\text { of signs }\end{array}$ & $\begin{array}{l}\text { Regression } \\
\text { of signs }\end{array}$ & $\begin{array}{l}\text { Simple } \\
\text { evolution }\end{array}$ & Transfer & $\begin{array}{l}\text { Simple } \\
\text { evolution }\end{array}$ & $\begin{array}{l}\text { Regression } \\
\text { of signs }\end{array}$ \\
\hline $\begin{array}{l}\text { Fetal } \\
\text { evolution }\end{array}$ & Prematurity & 0 & Prematurity & Death born & Prematurity & RCIU & 0 & Abortion & 0 & 0 \\
\hline Follow up CC & irregular & 0 & 0 & 0 & 0 & 0 & 0 & 0 & 0 & 0 \\
\hline CPN & 04 & 03 & 04 & 00 & 00 & 00 & 04 & 02 & 04 & 03 \\
\hline $\begin{array}{l}\text { Mode of } \\
\text { delivery }\end{array}$ & $\mathrm{CS}$ & $\mathrm{CS}$ & $\mathrm{CS}$ & $\begin{array}{l}\text { Vaginal } \\
\text { delivery }\end{array}$ & $\mathrm{CS}$ & $\mathrm{CS}$ & $\begin{array}{l}\text { Vaginal } \\
\text { delivery }\end{array}$ & Abortion & $\mathrm{CS}$ & $\mathrm{CS}$ \\
\hline Anesthesia & PDA & GA & RA & 0 & RA & PDA & PDA & 0 & PDA & PDA \\
\hline $\begin{array}{l}\text { Treatment } \\
\text { specific post- } \\
\text { operative }\end{array}$ & 0 & 0 & 0 & 0 & Diuretic-IEC & 0 & 0 & 0 & 0 & 0 \\
\hline Contraception & TSL & Advice & Advice & Advice & Advice & TSL & Advice & Advice & Advice & Advice \\
\hline $\begin{array}{l}\text { Specialized } \\
\text { consultation }\end{array}$ & 0 & Cardiology & Cardiology & 0 & Cardiology & 0 & 0 & 0 & 0 & 0 \\
\hline
\end{tabular}

The latter benefited surgical repair. The $50 \%$ of IAC had cardiac repercussions and $75 \%$ had cardiac signs on admission. We have on the other hand found 06 cases of persistence of the arterial canal (PAC) of which, one associated with an inter-ventricular communication (IVC). Three of these congenital heart diseases benefited of reconstructive surgery. Three cases of PCA presented a repercussion of congenital heart disease (Mitral regurgitation MR, Tricuspid regurgitation TR, Hypertrophic cardiomyopathy HCM) and 03 cases had cardiac signs on admission. For the 02 types of congenital heart diseases listed in our study, the repercussions of heart disease are dominated by NYHA II dyspnea, valvulopathy, cavitary hypertrophy. And the reason of admission was in the majority of cases, caesarian surgery (CS) prophylactic. After the evolution, an asystole type 
complication with immediate recovery after intensive care measures was listed on maternal side. On the fetal side, we recorded 02 deaths, 03 premature births and one intra-uterine delayed growth (IUDG). Compared to prenatal care, no patient had regular followed up care of heart disease. Only 04 patients completed a sufficient number of pre-natal consultations (PNC) that is 04 consultations or more. However, this was done by the midwives of CHU-GOB. No medical follow up care noted. For the delivery mode, we have identified $07 \mathrm{CS}$ of which one realized under general anesthesia (GA), 02 under rachianesthesia (RA) and 04 under peri-dural anesthesia (PDA) and 02 vaginal deliveries of which one performed under PDA and one concerns premature birth. A case of spontaneous abortion was noted. In postpartum, the patients benefited from standard postoperative treatment of adult intensive care unit. Only one patient required specific diuretic and inhibitive enzyme of conversion (IEC) therapy. Trump section ligature (TSL) was performed in two patients. And $30 \%$ of our population study was refered for cardiological consultation at the exit of the hospital.

Table 2: CARPREG score.

\begin{tabular}{|ll|}
\hline CARPREG points & $\begin{array}{l}\text { Risk cardiovascular } \\
\text { maternal complications }\end{array}$ \\
\hline 0 & $5 \%$ \\
\hline 1 & $27 \%$ \\
\hline$>\mathrm{Ou}=2$ & $75 \%$ \\
\hline
\end{tabular}

- NYHA functional class> II

- Cyanosis (room air saturation $<90 \%$ )

- Prior cardiovascular event

- Systemoc ventricular ejection fraction $<40 \%$

- Left heart obstruction (mitral valve area $<2 \mathrm{~cm}^{2}$ or aortic valve area $<1,5 \mathrm{~cm}^{2}$ or left ventricular outflow gradient of $>30 \mathrm{mmHg}$ )

Table 3: Maternal risk during patients pregnancy with congenital cardiopathy (heart disease).

\begin{tabular}{|c|c|}
\hline Risk & Criteria \\
\hline High risk of complications or death & $\begin{array}{l}\text { - Arterial pulmonary hypertension Syndrome of Eisenmenger } \\
\text { - Coarctation of the aorta } \\
\text { - Syndrome of Marfan with dilated aorta }>45 \mathrm{~mm} \\
\text { - Aortic stenosis narrowed symptomatic unique ventricle with systolic } \\
\text { altered, with or without derivation type «Fontan» }\end{array}$ \\
\hline $\begin{array}{l}\text { Moderate risk of complications } \\
(5 \text { to } 15 \%)\end{array}$ & $\begin{array}{l}\text { - Cyanogen cardiopathy non repaired, right ventricle systemic (under } \\
\text { aortic) circulation type «Fontan » with good functioning } \\
\text { - Tetralogy of Fallot operated with important arterial pulmonary } \\
\text { hypertension and dysfunction of right ventricle }\end{array}$ \\
\hline Low risk of complications $(<1 \%)$ & $\begin{array}{l}\text { - } \text { IAC isolated, repaired or not } \\
\text { - } \quad \text { IVC isolated, repaired or not } \\
\text { - Tearctation repaired with initial aorta in normal size } \\
\text { minimal arterial pulmonary tension }\end{array}$ \\
\hline
\end{tabular}

\section{DISCUSSION}

Regarding the prevalence of congenital heart disease, our study found a low prevalence compared to the literature $0.12 / 1000$ against 2.8 to $4.1 / 1000{ }^{4}$ This difference is explained by the fact that our study concerned only one hospital centre, therefore not representative of Madagascar population biasing the statistics. For the profile of the patients, the young maternal age found in our study would be related to the nature of the Malagasy population which is young. In addition, it is the age of procreation. The average gestational age found, also corresponds to a pregnancy not yet completed and only reinforces the physiopathology of pregnancy on congenital heart disease responsible of a fatal morbidity including prematurity and IUDG. ${ }^{4}$ As for the heart disease type, we recorded 06 cases of PAC of which one associated and 04 cases of IAC of which one associated. These results rejoin those in the literature that found a frequency of $40 \%$ of IAC, $15 \%$ of PCA, $10 \%$ of IVC and Tetralogy of Fallot. Only four cases of surgical repair have been identified which differ from the literature since heart diseases are generally operated at an early age in the presence of complication in developed countries. ${ }^{5}$ In fact, in Madagascar, heart surgery still remains undeveloped explaining the low rate of repair. The impact of heart diseases is dominated by NYHA II dyspnea and valvulopathy. Three-fifth of patients with heart disease repercussions had cardiac complications on admission. Additionally, 02 cases antecedents of decompensation were noted of which one presented cardiac complication on admission. These cardiac signs on admission are approximately 50\%. All this corresponds with CARPREG score (Table 2) which is designed to access the risks of maternal cardiovascular complications 
especially in the context of pregnancy on heart diseases. ${ }^{6}$ This score includes several factors of which NYHA II dyspnea and the antecedent of cardiac decompensation found in our study. With regard to prenatal hospital care, no preparation for pregnancy has been noted. Patients having performed sufficient number of PNC completed these with the midwife of the site of study, without specified follow up. The literature recommends, at first step, a preconceptional assessment that will determine the predisposing risk factors of fetal transmission of heart disease. ${ }^{7}$ Thus, we will have 03 groups of pathologies. A first group of heart diseases, not contraindicating the pregnancy which includes the IAC, PAC and tetralogy of Fallot without pulmonary arterial hypertension (PAHT) operated or not, which constitute the main congenital heart diseases of our study. And a second group of pregnancy of moderate cardiovascular risk as well as a third group at high risk contraindicating pregnancy.

As a second step, a regular and close follow up of pregnancy at a level III Maternity with multidisciplinary meeting, at least per trimester is required.

If the CS was in our study the most prescribed mode of delivery carried out under PDA in more than half of cases (04 cases). The literature recommends that pregnancy should be completed in the absence of serious cardiac disease and with the agreement of cardiologist.? However, the mode of delivery depends on the risk related to the pregnancy on congenital heart disease (Table III). Thus, in light of a low risk, particularly in the case of IVC, IAC non-operated and the tetralogy of Fallot listed in our study, the mode of delivery is to be discussed case by case and the PDA is recommended in the absence of contraindications. Whatever, mode of delivery is chosen. On the other hand, face to a moderate risk or high risk the CS under GA remains the technique of choice.

\section{CONCLUSION}

Congenital heart diseases are rare pathology. The context of pregnancy on congenital heart disease also is complex, since the physiological changes in the pregnancy add the pathophysiology of heart disease itself. Special care is therefore needed in order to reduce maternal fetal morbidity and mortality, as for, a planned pregnancy, a follow up at a level III maternity and multidisciplinary care involving cardiologist, gynecologist obstetrian, anesthetist reanimator and pediatrician. However, the type of heart disease, the treatment of heart disease, its cardiac repercussions and previous complications related to heart disease remain determinant keys of care choice.

\section{ACKNOWLEDGMENTS}

Authors would like to thank Chief of Anesthesiology department at the UHC-GOB who permit us to do the study and the medical and paramedical staff of anesthesiology department, UHC-GOB for their help to find all documents about heart disease cases.

Funding: No funding sources

Conflict of interest: None declared

Ethical approval: The study was approved by the Institutional Ethics Committee

\section{REFERENCES}

1. Jastron N, Irion O, Meyer P, Bouchardy J, Savoldelli GL. Maternal heart disease and pregnancy: a multidisciplinary care. Rev Med Suisse. 2011;7:2070-7.

2. Lewis G, Drife JO. Why mothers die 2000-2002_The sixth report of confidential enquiries into maternal and child Healths in the United Kingdom. In: Palmer G, Carr J, Kenway P. Health promotion in midwifery, principles and practice. 2nd ed. London: RCOG Press; 2006:25-35.

3. Song YB, Park SW, Lee HJ. Outcomes of pregnancy in women with congenital heart disease: a single center experience in Korea. J Korean Med Sci. 2008; 23: 808-13.

4. Blanche C, Rutz T, Vogt P, Mach F, Beghetti M, Bouchardy J. Congenital heart disease in adult: new population of patients, multidisciplinary care. Rev Med Suisse. 2013;9:1142-7.

5. Bettex D. Anesthesia in Congenital Heart Disease. In: Chassot PG. Accuracy of cardiac anesthesia. 4th ed. Paris: Masson; 2008:15.

6. Oakey. Diagnosis and treatment guide for high blood pressure. Eu Health Journal. 2003;24:761-81.

7. Bricker L, Clarke B, Freeman L, Fraser L, Nair V, Nelson-Piercy C. Heart disease and pregnancy. RCOG. 2011;13:1-6.

Cite this article as: Razafindrainibe $\mathrm{T}$, Rakotonomenjanahary S, Andrianirina M, Raveloson NE. Congenital heart diseases and pregnancy, Universitary Hospital Center of Gynecology Obstetrical of Befelatanana. Int J Reprod Contracept Obstet Gynecol 2019;8:3276-9. 